\title{
YAŞLI BİREYLER İÇİN WEB SAYFALARI TASARIMININ ERGONOMİK AÇIDAN İNCELENMESI*
}

\author{
İhsan ÖZER ${ }^{1}$, İsmail SARI ${ }^{2 \dagger}$ \\ ${ }^{1}$ Öğr.Gör., Pamukkale Üniversitesi, Denizli Teknik Bilimler MYO, Bilgisayar Teknolojileri Bölümü, Çamlık- \\ DENIZLİ, e-posta: ihsano@pau.edu.tr, ORCID No: http://orcid.org/0000-0002-5483-2190 \\ 2 Öğr.Gör., Pamukkale Üniversitesi, Denizli Teknik Bilimler MYO, Bilgisayar Teknolojileri Bölümü, Çamlık- \\ DENIZLİ, e-posta: ismailsari@pau.edu.tr, ORCID No: http://orcid.org/0000-0001-6280-0124
}

\section{YAŞLI BİREYLER İÇiN WEB SAYFALARI TASARIMININ ERGONOMIK AÇIDAN İNCELENMESİ}

\begin{tabular}{l}
\hline Anahtar Kelimeler \\
\hline Yaşlanma, \\
bilgi teknolojileri, \\
ergonomi, \\
geronteknoloji, \\
internet.
\end{tabular}

Öz

Son yıllarda iki önemli sosyokültürel eğilimi yașlyoruz. Bunlardan ilki, birçok gelișmiș ülkede 20. yüzyılda başlayan insan ömrünün belirgin şekilde artması; ikincisi ise, bilgi teknolojilerindeki gelişmeye bağlı olarak bilgisayar ve internet kullanımının hızla benimsenmesidir. Bu durum günlük yaşamda güvenlik ve bağımsızlığı artırarak, yașlıların yașamlarını iyileştirmeye katkı sağlamaktadır. Teknoloji aynı zamanda yaşla ilgili sınırlamaların önlenmesinde, sağlıklı yaşlanmanın sürdürülmesinde ve bilișsel yeteneklerin kaybedilmesini engellemede de rol oynar. Geronteknoloji olarak adlandırlan bu yeni alanin temel kaygısı, yaşlı insanlarda teknoloji kullanımının öngörülerini anlamak, yaşla birlikte ortaya çıkan normatif değişikliklerin teknolojiyle nasıl etkileștiğini ve daha iyi teknoloji ürünlerinin nasıl tasarlanacağını belirlemektir. Bu bağlamda teknolojinin benimsenmesini ve kullanımını etkileyen yaşla ilgili değișikliklerin gözden geçirilmesi, sonra da bu değişikliklerin tasarıma olan etkilerinin ne olduğunun anlaşılması gerekir. Yaşlıların bilgi teknolojisi kullanımının belirlenmesi amacıyla yapılan bu çalışma Denizli kentsel kesimde 60 yaș üzerinde bilgisayar kullanıcısı olan, yașlı bireylerin internet ortamında kullandıkları web sayfalarının temalarından kaynaklı karşılaştıkları zorluklar, örneklem üzerinde değerlendirmeleri ve web sayfası kullanımı sırasında karşılaş̧tıkları zorlukların çözümü sürecinin ergonomik olarak ele alınması, web sayfası tasarımında yaşlı bireylerin karșılaşabilecekleri zorlukların göz önünde bulundurularak tasarlanmasını hedeflemektedir. Araştırmada bilgisayar kullanan yaşlı bireyin internet kullanımına yönelik beklentileri, benimsenmesine engel olușturan algıları ve web sayfalarının tasarımı; anket yöntemi kullanılarak ölçülmüsstür. Web sayfalarının ergonomik tasarımı, yaşlı bireyin bilgi teknolojilerine yönelik; kullanım, beklenti, güvenlik kaygılarını ortadan kaldıracaktır.

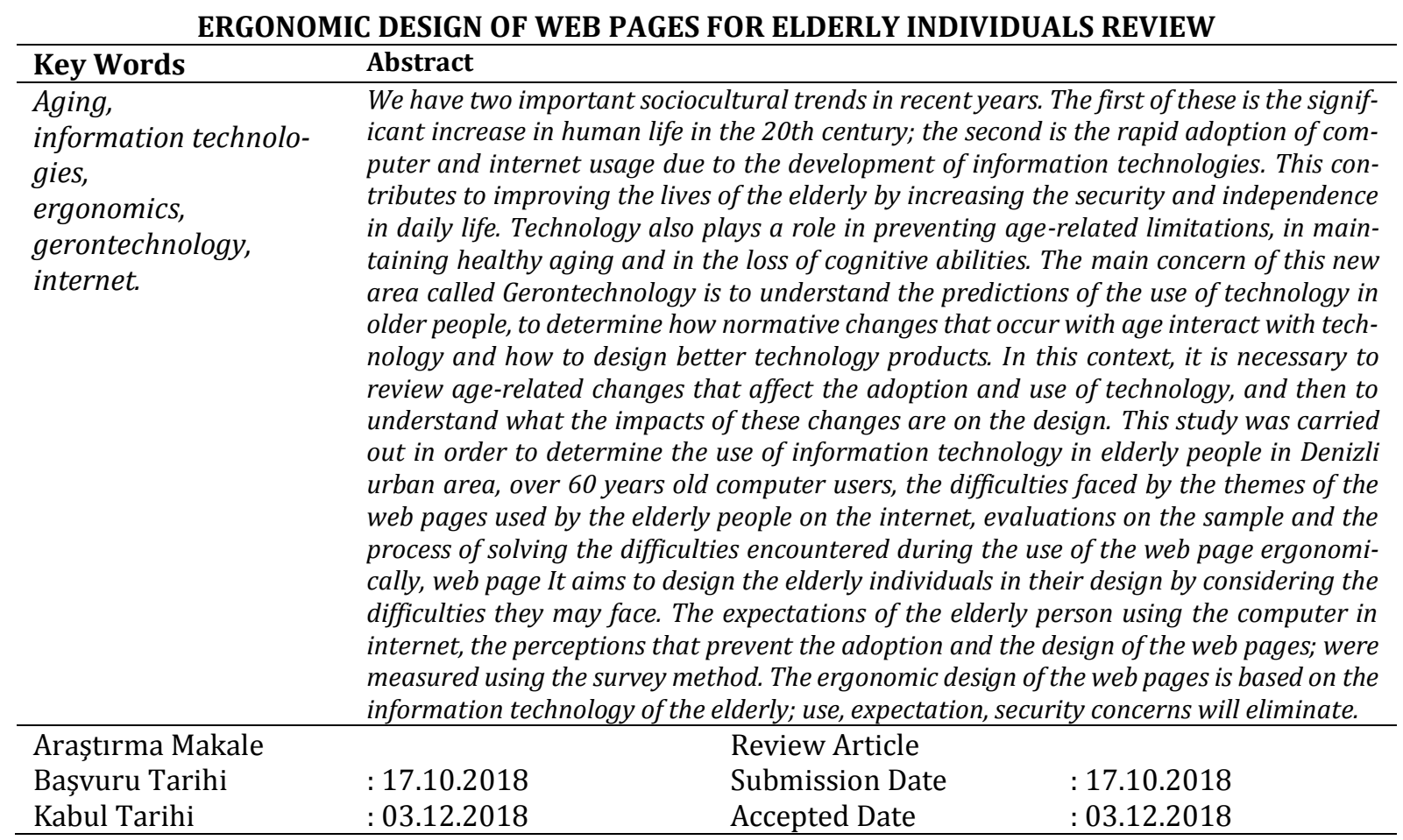

\footnotetext{
*Bu makale 28-30 Eylül 2018 tarihlerinde Erzurum'da gerçekleștirilen “24. Ulusal Ergonomi Kongresi”nde sunulan tebliğin genișletilmiş halidir.

† Sorumlu Yazar; Tel: 0.532.552 2499
} 


\section{Giriş}

Bilgi teknolojilerindeki gelişim, bilgi paylaşımını olumlu yönde etkilemektedir. Bilgi ağı kullanımının yaygınlaşması, bir anlamda her yaşa ve her düzeye uygun bir șekilde tasarlanmasını gerektirmektedir. Bilgi teknolojileri gelişimine bağlı olarak kullanımı yaygınlașan internet ağının; yașlı bireylerin kullanımının aktif bir şekilde sağlanması, internet sayfalarının yaşlı bireyler tarafından kolaylıkla kullanımının gerçekleşmesi, web sayfalarının ergonomisi açısından önem kazanmaktadır. Bilgi ve iletişim teknolojileri pek çok profesyonel ve özel alanlarda kullanıldığı gibi yaşlı bireyler tarafından da kabul görmekte, kullanılmaktadır (Arning ve Ziefle, 2009). İletişim, bilgiye erişim ve günlük yașam aktivitelerini kolaylaştırması yanında, sosyal ilişkiler, boş zaman ve eğlence firsatları sağlaması ve yaşam boyu öğrenme alışkanlıklarını geliştirmesi, hizmetlere ve bakıma erişmek için yeni teknolojileri kullanma olanağı sağlaması, yașlı bireylerin yașamlarını bağımsız ve aktif olarak sürdürmelerini sağlaması önemli avantajlar olarak düşünülebilir (Arning ve Ziefle, 2009; Gonzalez vd., 2015; Kalınkara vd., 2016). Bilgi İletişim Teknolojileri (BİT) gelişimine bağlı olarak teknoloji kullanımına yönelik eğilimler artmaktadır. Teknoloji yalnızca, üretim alanlarında kalmayıp, iletişim ve sosyal alanlarda da yararlı olmaktadır. Ancak, BİT'in bu olumlu özelliklerine karşın günümüz bilgi teknolojisi ürünleri, yüksek bilgisayar kullanma becerisine sahip genç insanlara uygun tasarlanmış, yaşlı bireyler ise marjinal bir grup olarak sistemin dlşında kalmıştır. Yaşlı bireyi hedeflemeyen bu tasarımlar, fiziksel, psikolojik koşullar, bilgi düzeyindeki değişiklikler ve farklılıklar nedeniyle, yaşlı bireyler genellikle karmaşı etkileşimli ortamlarda kendilerini çaresiz hissetmekte ve büyük bir psikolojik engelle karşılaşmaktadır. İstatistikler, gelişmekte olan ülkelerde yaşlı bireylerin, eğitim düzeylerine bağlı olarak ortalama yarısının "teknoloji fobisi" olduğunu, pazarda çeşitli elektronik cihazlarla karşı karşıya kaldıklarında üzüntü verici birçok sorunla karşılaştıkları, bilgisayar kullanamadıkları, kısa mesaj gönderemedikleri, internet sayfalarında rahatça dolaşamadıkları veya ATM makinesini kullanmada sorun yaşadıklarını göstermektedir. Halbuki gelişmiş ülkelerde, yaşlı bireyler iyi eğitimli, zengin bilgisayar bilgisine ve operasyonel deneyime sahiptir. Yaşlı bireyler teknik olarak yetenekli olsalar da, işitme, görme ve fiziksel fonksiyonların azalması, yavaş hareket, zayıf esneklik, koordinasyon yeteneği ve bellek azalması gibi yaşlanmanın yol açtığı fiziksel ve psikolojik değişikliklerle yüzleşmek zorundadırlar. Bu sorunlar, yaşlı bireylerin interaktif cihazları kullanmalarında zorluklara neden olmaktadır (Zhou ve Shen, 2016; Kalınkara vd., 2016).

Teknoloji yaşla ilgili ortaya çıkan bu olumsuzlukların azaltılmasında önemli destekler sağlar; günlük yaşamda güvenlik ve bağımsızlığı artırarak, yaşlı bireylerin yaşamlarını iyileştirme potansiyelini artırır (Rogers vd., 2005; Kalınkara vd., 2016). Ancak araştırmalar, BİT'in yaşlı bireylerin refahı üzerinde olumlu psikososyal etkilerinin kesin olmadığını, bellek ve dikkat gibi bilişsel becerilerin geliştirilmesindeki etkisinin çok zayıf olduğunu göstermektedir. Spesifik çalışmaların sonuçlarına göre, yalnızca bilișsel yeteneklerin yaşlı erişkinlerin bilgisayar kullanımını öngörmede yeterli olmadığı, bunun yanında bilgisayar öz-yeterliliği ve bilgisayar kaygısı gibi tutum değişkenlerinin de dikkate alınması gerektiği ortaya çıkmıştır (Gonzalez vd., 2015). Yaşlandıkça bireylerin vücut esnekliği ve koordinasyonu bozulmakta (Zhou ve Shen, 2016), fiziksel ve bilişsel işlevleri azalmakta; azalan bu işlevleri telafi edecek çok çeşitli yardımcı teknolojiler bulunmaktadır. Bilgi ve iletişim teknolojileri, özellikle de hareket yeteneği kısıtlamaları, fiziksel ve psikolojk değişimler durumunda; bağımsızlık, sosyalleşme, sağlığın teşviki ve geliştirilmesi konularında yaşlı bireylere yardım edebilir.

Yaşlılık süreci yalnızca fiziksel değişiklikleri içermez, aynı zamanda psikolojik ve sosyal etkileri de söz konusudur (Enwald vd., 2016). Yaşlı bireyler kavrama ve algılama eksikliği nedeniyle özellikle küçük ürünleri kullanmada sorun yaşarlar (Zhou ve Shen, 2016). En kötü senaryoda, bu durum toplumdan dişlanmaya, sosyal aktivitelerden uzaklaşmaya neden olabilir. Mervyn ve Allen (2012) mobil bilgi teknolojisinin sosyal dişlanmayı azaltmaya olan etkisini araştırmışlar; mobil bilgi teknolojisinin, yaşlı insanların güçsüzleștirilmesi veya güçlendirilmesi için bir araç görevi görebileceğini belirtmișlerdir. Örneğin, Hill vd. (2015)'in bulguları "gri" dijital bölünme kanıtını desteklemektedir. Mobil bilgi teknolojisi kullanımı, yaşlıların sosyal iletişimi sürdürmesine ve bağımsızlık artışına izin vermekte, yașlı birey aile üyeleri ve yakınları ile kolay iletișim kurabilmektedir (Enwald vd., 2016).

Teknolojinin tüm bu olumlu katkılarına karşın, yaşlı bireylerin kapasite ve sınırlamaları (görme, işitme, algılama, motor beceriler, hafıza, bilgi işleme, anlama gibi) ürün tasarımında pek dikkate alınmamaktadır. Yaşlı bireylerin yeni teknolojileri ne ölçüde kullandıkları, yeni teknolojilerin benimsenmesi (tutumlar), teknoloji tasarımının yaşlıların performansına etkisi (araçların tasarımı) ve bu konuda yetişkin eğitiminin optimize edilmesi (yaşlı-özel eğitim araştırmaları) araștırılması gereken önemli konular arasında yer almaktadır. Gelecek on yılda insan faktörü araştırmalarının odağını oluşturacak yeni araştırma 
alanlarının gözden geçirilmesi ve yaşlı çalışmalarının bu alandaki yerinin ele alınması gerekir. $\mathrm{Bu}$ araștırma alanları arasında bilgisayar sistemleri (ev izleme sistemleri), sağlık teknolojileri (telesağlık), robotik ve otomatik sistemler (hız sabitleme) yer almaktadır. İnsan faktörleri araştırmaları ve yașlıların kullandığı teknolojiyi optimize etme ile ilgili zorlukların da dikkate alınması gerekir (Rogers vd., 2005).

Son zamanlarda yürütülen araştırmalar, internet kullanımının yaşlı bireylerde sosyal izolasyonun bir sonucu olan yalnızlığı önemli ölçüde azalttığı konusundaki argümanları desteklemektedir (Hill vd., 2015). Gero(n)teknoloji olarak adlandırılan bu yeni gelişme alanındaki başlıca endişeler, yaşlılıkta normatif değişikliklerin teknoloji ile etkileşimi nasıl etkilediğini anlamak ve daha iyi teknoloji ürünlerinin nasıl tasarlanacağını belirlemek ve yașlı insanların teknoloji kullanımı konusundaki öngörülerini anlamaktır (Kalınkara vd., 2016; Kalınkara vd., 2016). İlgi daha çok algı, biliş, psikomotor performans ve yaşam süresince gerçekleșen yeni bilgi değişikliklerine bireyin tepkileri üzerine odaklanmaktadır. Bu tür değişiklikler araçla insan arasında farklı etkileşimlere yol açmaktadır. Önce, teknolojinin benimsenmesini ve kullanımını etkileyen, yaşa bağlı değişen yetenekler gözden geçirilir. Sonra bireydeki bu değişimlerin tasarıma olan etkileri ele alınır (Charness ve Boot, 2009).

Teknoloji kullanımında bireysel farklılıkların anlaşılması, yaşlı bireyleri de içerecek ürün tasarımı ve eğitimi anlamına gelir. Bu durum gelişen ve değișen bireysel farklılıkların ürün tasarımında dikkate alınmasını, kullanımda esneklik sağlayacak ergonomik tasarımları gerektirir. Bu çalıșmanın amacı, yaşlıların internet kullanımı sırasındaki beklentileri ve internet kullanımına engel oluşturan (güvenilirlik) algıları ile internet web sayfalarının ergonomik tasarımlarına ilişkin tutumlarını belirlemektir.

\section{Materyal ve Yöntem}

Araştırma, Denizli kent merkezinde yaşayan 60 ve üzeri yaşlardaki bireyler üzerinde yürütülmüştür. Denizli kentsel nüfusu 630 bin civarındadır, bu nüfusun yaklaşık \% 15'i 60 yaş ve üzerindedir (TUIK, 2017). Bunların da yaklaşık üçte biri en az lise öğrenimi görmüştür. Bilgisayar kullanıcılarının daha çok lise ve üstü ögrrenim görenler olduğu dikkate alınarak, araştırmaya katılanlar bilgisayar kullanıcısı olan ve internet kullananlar arasından seçilmiştir. Bu amaçla rastgele 108 yaşlı birey araştırma kapsamına alınmıştır.

Yaşlıların bilgi teknolojilerinden yararlanarak in- ternet kullanımı, web sayfalarının tasarımını belirlemede anket formu kullanılmıştır. Anketin hazırlanmasında çeşitli kaynaklardan (Festervand vd., 2011; Kalınkara vd., 2016) yararlanılmıştır. Anket iki boyuttan oluşmaktadır. İlk bölümde yaşlı bireye ve teknoloji kullanımına ilişkin bilgiler, ikinci bölümde internet sayfası kullanımına yönelik sorular ele alınmıștır. Bu bölümde yer alan ifadelere verilen yanıtlar 5'li dereceleme ile puanlanmıştır. İnternet kullanımına yönelik 23 soru sorulmuștur. Bu sorulardan; "Internet sayfalarına sesli erişebilmenin önemli olduğunu düşünüyorum" ve "İnternet sayfasındaki açllır menülerin kullanışlı olduğunu düşünüyorum" soruları anketten çıkarılmıştır. İnternet kullanımına yönelik 21 soru için yapılan Cronbach Alfa geçerlilik testi 0.726 olarak bulunmuştur. Verilerin değerlendirilmesinde SPSS 17.0 istatistik programı kullanılmıştır. Araştırmada kullanılan ölçekler aşağıda detaylı olarak açıklanmıştır.

Araștırmada cinsiyet, yaş, eğitim, medeni durum, gelir ve internet kullanım süreleri t testi ve varyans analizi (ANOVA) ile ele alınmıştır. Alt boyutlarla yaşam doyumu ilişkisini belirlemede korelasyon analizi uygulanmıştır.

\section{Bulgular}

Denizli kentsel kesimde yaşlı bireylerin web sayfalarını kullanımı, web sayfalarının kullanımı sırasındaki beklentileri, web sayfalarının güvenliği ile ilgili beklentileri, web sayfalarının ergonomisi konulu bu çalışmada bulgular bireyin internet kullanımına ilişkin bilgiler, internet sayfası kullanımına yönelik tutumlar; web sayfalarının kullanımı, web sayfalarından beklenti, ergonomi ve güvenlik başlıkları altında incelenmiştir.

\subsection{Yaşlı Bireye ve Teknoloji Kullanımına İliş- kin Bilgiler}

Araştırma kapsamına alınan yaşlı bireylere anketin birinci bölümünde sayılara ilişkin veriler için frekans analizi yapılmıştır. Buna göre ankete katılanların tamamı bilgisayar kullanıcısıdır. Yaş aralığ 60-82 arasında değişmektedir. Yaşlıların \% 72.2'si erkek, \% 27.8'i kadındır. Lise öğrenimi görenler \% 29.6, ön lisans, lisans ve lisansüstü öğrenim görenler \% 70.4 oranındadır. Evde tek baŞına yaşayanlar \% 27.8, eşi ve çocukları ile birlikte yaşayanlar \% 72,2 oranındadır. Yarıdan çoğu (\% 56.6) kamu çalışanıdır. Gelirini orta olarak belirtenler \% 52.8,düşük olarak belirtenler \% 24.1, yüksek olarak belirtenler ise \% 23.1 şeklindedir. Yaş grupları sıklık raporu incelendiğinde; Ankete katılan bireylerin \% 69.4'ü 60-69 yaş aralığında, \% 30.6'sı 70+ yaş aralığındadır (Tablo 1). 
Tablo-1. Yaş Grupları Dağılımı

\begin{tabular}{ccc}
\hline Yaş sınıflaması & Frekans & $\%$ \\
\hline $60-64$ & 42 & 38.9 \\
$65-69$ & 33 & 30.6 \\
$70-74$ & 20 & 18.5 \\
$75+$ & 13 & 12.0 \\
Toplam & 108 & 100.0 \\
\hline
\end{tabular}

Ankete katılan yaşlı bireylerin interneti kullanma süreleri ise; 1 -5 yll \% 13.9, 6-10 yll \% 38.9, 11-15 yıl \% 19.4, 15 yıldan daha fazla \% 27.8 oranındadır. Yalnızca bilgisayar kullanarak internete erişenlerin oranı \% 16.7, akıllı telefon aracılığı ile internete erişenlerin oranı \% 32.4, Her ikisini kullanarak erișenlerin oranı ise $\% 50.9$ olarak belirlenmiştir. Ankete katılanların \% 80. 6'sı her gün internete girdiklerini, \% 13'ü haftada 3-4 kez internete girdiklerini, $\% 6.5$ ' $\mathrm{i}$ ise ayda 1-2 kez ile 34 ayda bir kez şeklinde belirtmişlerdir. İnternet kullanan yaşlı bireylerin; \% 34.3'ü günde bir saatten az internet kullandıkları, \% 65.7'sinin ise günde 1 saatten fazla internet kullandıkları görülmüștür.

\section{2.İnternet Web Sayfası Kullanımına Yönelik Tutumlar}

Araştırma kapsamına alınan yaşlı bireylerin internet kullanımına ilişkin beklentileri genel beklentiler, kullanım, ergonomi, güvenlik ve kolaylık olmak üzere 4 alt boyutta ele alınmıştır. Alt boyutlarda yer alan anket soruları Tablo 2'de verildiği gibidir.

İnternet kullananların alt boyutları cinsiyetlerine göre anlamlı bulunmamıştır ( $\mathrm{p}>0.05)$. Bunlardan genel beklentiler, güvenlik ve kolaylık alt boyutlarında yer alan cümleler olumlu, kaynaklar, kullanım ve ergonomi alt boyutlarındaki cümleler olumsuzdur.

Araştırmada farklı web sayfalarını kullanan yaşlı bireylerin, sayfaların ergonomik tasarmmlarına ilişkin; \% 65'i internet sayfalarındaki metinleri okumakta zorlanıyorum, \% 65.4'ü internet sayfalarındaki çok fazla renk olması sayfa kullanımımı zorlaştırıyor, \% 76'sı internet sayfalarındaki arka plan renkleri gözlerimi yoruyor, \% 31.4'ü internet sayfalarındaki ikonların uygun olduğunu düşünüyorum, \% 63.9'u internet sayfalarındaki metin karakterlerinin küçük olduğunu düşünüyorum, \% 72.2'si arka planı beyaz olan internet sayfaları daha kullanışlı, olarak ifade etmişlerdir.

Ankette web sayfalarının güvenliğine ilişkin; \%77.8'i internet ortamında isteğim dışında açılan sayfalar beni endişelendiriyor, \% 53.7'si banka işlemlerini internet ortamında yapmak istemiyorum şeklinde cevap vermişlerdir.

\section{Tablo-2. İnternet Kullanımına İlişskin}

\section{Alt Boyut Anket Soruları}

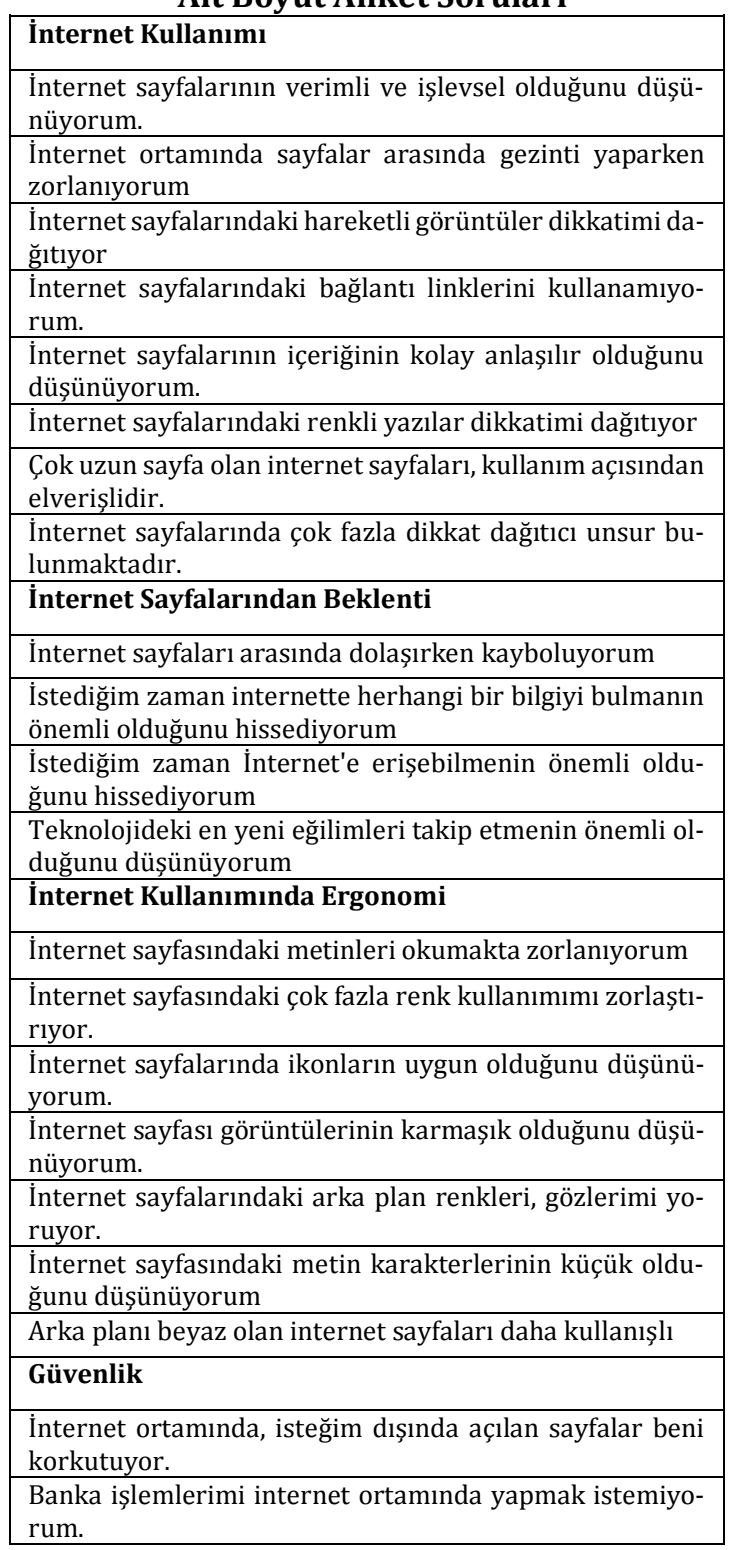

Ankette internet sayfalarının kullanımına ilişkin; $\%$ 53.7' si internet ortamında sayfalar arasında gezinti yaparken zorlanıyorum, \% 75'i internet sayfalarındaki hareketli görüntüler dikkatimi dağıtıyor, \% 47.3' ü internet sayfalarındaki bağlantı linklerini kullanamıyorum, \% 78.7'si internet sayfalarında çok fazla dikkat dağıtıcı unsur bulunmaktadır, \% 64.8'i internet sayfalarının verimli ve işlevsel olduğunu düşünüyorum, \% 38.9'u internet sayfalarının içeriğinin kolay anlaşllır olduğunu düşünüyorum, \% 45.4'ü internet sayfalarındaki açılır menülerin kullanışlı olduğunu düşünüyorum, \% 63.9'u internet sayfalarındaki renkli yazılar dikkatimi dağıtıyor şeklinde cevap vermişlerdir. 
Ankete katılanlar internet sayfalarındaki beklentilerine ilişkin; \% 47.3'ü internet sayfaları arasında dolaşırken kayboluyorum, \% 81.5'i istediğim zaman internette herhangi bir bilgiyi bulmanın önemli olduğunu hissediyorum, \% 73.2'si istediğim zaman internete erişebilmenin önemli olduğunu hissediyorum, \% 71.3'ü teknolojideki en yeni eğilimleri takip etmenin önemli olduğunu düşünüyorum, \% 58.4'ü internet sayfası görüntülerinin karmaşık olduğunu düşünüyorum, \% 62.9'u internet sayfalarına sesli erişebilmenin önemli olduğunu düşünüyorum şeklinde düşüncelerini belirtmişlerdir.
Katılımcların cinsiyetlerine göre internet kullanımı aritmetik ortalaması ( $p>0.05)$ anlamlı bulunmamıştır.

İnternet sayfalarındaki beklentilerine göre aritmetik ortalaması, kadın ve erkekler arasında ( $p>0.05)$ anlamlı bir farklılık bulunmamıştır.

İnternet sayfalarının ergonomik tasarımlarına göre aritmetik ortalaması, kadın ve erkekler arasında ( $p>0.05$ ) anlamlı bir farklılık bulunmamıştır.

İnternet sayfalarının güvenliği ile ilgili soruların aritmetik ortalaması, kadın ve erkekler arasında anlamlı bir farklılık bulunmamıștır (Tablo 3).

Tablo-3. Kadın ve Erkek Yaşlı Bireylerin; İnternet Sayfalarının Kullanım, Beklenti, Ergonomi ve Güvenlik Beklentilerine İlișkin Algı Puanları Karșılaștırması.

\begin{tabular}{|c|c|c|c|c|c|c|c|c|c|}
\hline \multirow{3}{*}{ Değişken } & \multicolumn{2}{|c|}{ Varyans Eşitliği } & \multicolumn{7}{|c|}{ T Testi } \\
\hline & \multirow[b]{2}{*}{$\mathrm{F}$} & \multirow{2}{*}{$\begin{array}{l}\text { Anlamlılık } \\
\text { Düzeyi }\end{array}$} & \multirow[b]{2}{*}{$\mathrm{t}$} & \multirow[t]{2}{*}{ df } & \multirow{2}{*}{$\begin{array}{c}\text { İki Yönlü } \\
\text { Anlamlılık } \\
\text { Düzeyi }\end{array}$} & \multirow{2}{*}{$\begin{array}{l}\text { Ortalama- } \\
\text { lar arası } \\
\text { fark }\end{array}$} & \multirow{2}{*}{$\begin{array}{c}\text { Standart } \\
\text { Hata Farkı }\end{array}$} & \multicolumn{2}{|c|}{ Farkın Güven Aralığı } \\
\hline & & & & & & & & Alt & Üst \\
\hline \multirow[t]{2}{*}{ Kullanım } & 0.096 & 0.758 & 0.576 & 106 & 0.566 & $0 ., 07596$ & 0.13184 & -0.18543 & 0.33735 \\
\hline & & & 0.600 & 57.347 & 0.551 & 0.07596 & 0.12657 & -0.17746 & 0.32938 \\
\hline \multirow[t]{2}{*}{ Beklenti } & 0.661 & 0.418 & 0.786 & 106 & 0.434 & 0.11648 & 0.14820 & -0.17734 & 0.41030 \\
\hline & & & 0.779 & 98.488 & 0.438 & 0.11648 & 0.14944 & -0.18007 & 0.41303 \\
\hline \multirow[t]{2}{*}{ Ergonomi } & 2.024 & 0.158 & -0.338 & 106 & 0.736 & -0.04396 & 0.12996 & -0.30161 & 0.21370 \\
\hline & & & -0.374 & 65.710 & 0.710 & -0.04396 & 0.11753 & -0.27863 & 0.19072 \\
\hline \multirow[t]{2}{*}{ Güvenlik } & 0.347 & 0.557 & 0.547 & 106 & 0.586 & 0.13462 & 0.24631 & -0.35372 & 0.62295 \\
\hline & & & 0.558 & 55.017 & 0.579 & 0.13462 & 0.24111 & -0.34858 & 0.61781 \\
\hline
\end{tabular}

Eğitim düzeyleri ile internet sayfalarının ergonomik kullanımı arasında anlamlı bir farklılık yoktur ( $\mathrm{p}>0.05)$.

Ankete katılan yaşlı bireylerin eğitim düzeylerine göre, internet sayfalarının güvenliğine ilişkin beklentilerinde anlamlı bir farklılık var$\operatorname{dır}(\mathrm{p}<0.05)$. Buna göre eğitim düzeyi azaldıkça, güvenlik hisleri de azalmaktadır. Eğitim düzeyleri azaldıkça, bankaların web sayfalarını güvenli bulmadıklarından; banka ișlemlerini, web sayfalarını kullanarak yapmamaktadırlar.

Ankete katılanların eğitim düzeylerine göre internet sayfalarındaki beklentileri ve internet sayfalarının kullanımına ilișkin beklentileri boyutlarında fark anlamlı bulunmamıştır $(\mathrm{p}<0.05)$. (Tablo 4).

Tablo 4. Eğitim Düzeyleri ile İnternet Sayfalarının Ergonomisi, Kullanımı, Beklenti ve Güvenliğine İlişkin Algı Puanları Karşılaştırması

\begin{tabular}{|c|c|c|c|c|c|c|}
\hline Değişken & & $\begin{array}{l}\text { Kareler Top- } \\
\quad \text { lamı }\end{array}$ & $\mathrm{df}$ & $\begin{array}{c}\text { Kareler orta- } \\
\text { laması }\end{array}$ & $\mathrm{F}$ & $\begin{array}{c}\text { Anlamlılık } \\
\text { Düzeyi }\end{array}$ \\
\hline \multirow[t]{3}{*}{ Kullanım } & Gruplar Arası & 0.358 & 3 & 0.119 & 0.313 & 0.816 \\
\hline & Grup İçi & 39.687 & 104 & 0.382 & & \\
\hline & Toplam & 40.046 & 107 & & & \\
\hline \multirow[t]{3}{*}{ Beklenti } & Gruplar Arası & 0.691 & 3 & 0.230 & 0.387 & 0.763 \\
\hline & Grup İçi & 61.991 & 104 & 0.596 & & \\
\hline & Toplam & 62.682 & 107 & & & \\
\hline \multirow[t]{3}{*}{ Ergonomi } & Gruplar Arası & 2.758 & 3 & 0.919 & 2.650 & $0.053^{*}$ \\
\hline & Grup İçi & 36.072 & 104 & 0.347 & & \\
\hline & Toplam & 38,830 & 107 & & & \\
\hline \multirow[t]{3}{*}{ Güvenlik } & Gruplar Arası & 14.672 & 3 & 4.891 & 4.067 & $0.009 * *$ \\
\hline & Grup İçi & 125.057 & 104 & 1.202 & & \\
\hline & Toplam & 139.729 & 107 & & & \\
\hline
\end{tabular}

${ }^{*} \mathrm{p}<0,05{ }^{* *} \mathrm{p}<0,01$ 
Algılanan gelir düzeyleri ile internet sayfalarının; kullanımı, internet sayfalarından beklenti, internet sayfalarının ergonomisi ve güvenlik alt boyutlarında, algı puanları için yapılan test sonucunda gelir düzeyleri arasındaki fark anlamlı bulunmamıştır $(\mathrm{p}<0.05)$ (Tablo 5).

Tablo-5. Algılanan Gelir Düzeyleri ile İnternet Sayfalarının Kullanımı, Beklentileri, Güvenlik ve Ergonomisine İlişkin Algı Puanları Karşılaştırması

\begin{tabular}{|c|c|c|c|c|c|c|}
\hline Değişken & & $\begin{array}{l}\text { Kareler Top- } \\
\text { lamı }\end{array}$ & $\mathrm{df}$ & $\begin{array}{c}\text { Kareler Orta- } \\
\text { laması }\end{array}$ & $\mathrm{F}$ & $\begin{array}{l}\text { Anlamlılık } \\
\text { Düzeyi }\end{array}$ \\
\hline \multirow[t]{3}{*}{ Kullanım } & Gruplar Arası & 1.066 & 2 & 0.533 & \multirow{3}{*}{0.909} & \multirow{3}{*}{0.406} \\
\hline & Grup İçi & 61.616 & 105 & 0.587 & & \\
\hline & Toplam & 62.682 & 107 & & & \\
\hline \multirow[t]{3}{*}{ Beklenti } & Gruplar Arası & 0.104 & 2 & 0.052 & \multirow{3}{*}{0.136} & \multirow{3}{*}{0.873} \\
\hline & Grup İçi & 39.942 & 105 & 0.380 & & \\
\hline & Toplam & 40.046 & 107 & & & \\
\hline \multirow[t]{3}{*}{ Ergonomi } & Gruplar Arası & 0.434 & 2 & 0.217 & \multirow{3}{*}{0.593} & \multirow{3}{*}{0.555} \\
\hline & Grup İçi & 38.396 & 105 & 0.366 & & \\
\hline & Toplam & 38.830 & 107 & & & \\
\hline \multirow[t]{3}{*}{ Güvenlik } & Gruplar Arası & 1.256 & 2 & 0.628 & \multirow{3}{*}{0.476} & \multirow{3}{*}{0.622} \\
\hline & Grup İçi & 138.473 & 105 & 1.319 & & \\
\hline & Toplam & 139.729 & 107 & & & \\
\hline
\end{tabular}

Katılımcıların internet kullanımı, internet sayfalarının güvenliği, internet sayfalarından beklentileri ve internet sayfalarının ergonomisi arasındaki ilişkilerin belirlenmesi amacıyla korelasyon analizi yapılmıştır. Bu sonuçlara göre; internet sayfalarının kullanımı ile internet sayfalarından beklenti, internet sayfalarının güvenliği ve internet sayfalarının ergonomisi arasında 0.01 düzeyinde anlamlı bir ilişki bulunmuştur. Aynı şekilde ergonomi ile kullanım ve güvenlik arasında 0.01 düzeyinde doğrusal yönde anlamlı bir ilişki bulunmuştur (Tablo 6).

Tablo-6. Korelasyon Analizi

\begin{tabular}{|l|c|c|c|c|}
\hline Değişkenler & Kullanım & Beklenti & Ergonomi & Güvenlik \\
\hline Kullanım & 1 & $0.372^{* *}$ & $0.498^{* *}$ & $0.437^{* *}$ \\
\hline Beklenti & $0.372^{* *}$ & 1 & 0.052 & 0.142 \\
\hline Ergonomi & $0.498^{* *}$ & 0.052 & 1 & $0.303^{* *}$ \\
\hline Güvenlik & $0.437^{* *}$ & 0.142 & $0.303^{* *}$ & 1 \\
\hline$* * \mathrm{p}<0,01$ & \multicolumn{4}{l}{}
\end{tabular}

Ankete katılan yașlı bireylerin \% 69.4'ü 60-69 yaș aralığındadır. Bağımsız örnekler testi uygulandığında yaş grupları ile internet kullanımı, internet sayfalarından beklenti ve internet sayfalarının ergonomisi arasında ( $p>0.05)$ anlamlı bir ilişki bu- lunmamıștır. Ancak internet sayfalarının güvenliği noktasında ise anlamlı bir ilişki kurulmuştur $(\mathrm{p}<0.05)$ Yaş ilerledikçe internet sayfalarının güvenliği konusunda kayglların arttığı, güvenlik unsuru gerektiren web sayfalarının (banka) kullanım oranının düştüğü görülmüştür ( Tablo 7).

Tablo-7. Yaş Grupları ile İnternet Sayfası Kullanımı, Ergonomi, Beklenti ve Güvenlik Algıları

\begin{tabular}{|l|c|c|c|c|c|}
\hline \multirow{2}{*}{ Kullanım } & \multicolumn{5}{|c|}{ T Testi } \\
& $\mathrm{t}$ & $\mathrm{df}$ & Anlamlılı Düzeyi & $\begin{array}{c}\text { Ortalamalar arası } \\
\text { fark }\end{array}$ & Standart Hata Farkı \\
\hline \multirow{2}{*}{ Beklenti } & 0.304 & 106 & 0.762 & 0.03327 & 0.10956 \\
\cline { 2 - 6 } & 0.288 & 54.459 & 0.774 & 0.03327 & 0.11549 \\
\hline \multirow{2}{*}{ Ergonomi } & 0.40 & 106 & 0.968 & 0.00636 & 0.16064 \\
\hline \multirow{2}{*}{ Güvenlik } & 0.41 & 66.377 & 0.967 & 0.00636 & 0.15529 \\
\cline { 2 - 6 } & -1.736 & 106 & 0.086 & -0.19788 & 0.11401 \\
\hline${ }_{*}^{*} \mathrm{p}<0,5$ & -1.853 & 71.778 & 0.068 & -0.19788 & 0.10679 \\
\cline { 2 - 6 } & -2.048 & 106 & $0.043^{*}$ & -0.48182 & 0.23523 \\
\hline
\end{tabular}


Ankete katılan yaşlı bireylerin, 70+ yaş aralığında bulunanların \% 70'i internet sayfasındaki metinleri okumakta zorlanıyorum. İnternet sayfasında çok fazla renk kullanımı; 70+ yaş aralığında bulunan yaşlı bireylerin, \% 72'sinin web sayfası kulla- nımını zorlaştırıyor. Yaş ilerledikçe web sayfalarında çok fazla renk kullanıldığını belirtenlerin oranı artmaktadır. Internet sayfalarının metin karakterlerinin küçük olduğunu düşünüyorum algısı; 70+ yaş aralığında \%72 iken, 60-69 yaş aralı̆̆ında \% 60'dır (Tablo 8).

Tablo-8. Yaş Grupları ile Web Sayfası Kullanımına İlişkin; “Metinleri Okuma, Çok Fazla Renk Kullanımı, Metin Karakterlerinin Boyutu” Algısı

\begin{tabular}{|c|c|c|c|c|c|c|c|}
\hline & & & \multicolumn{4}{|c|}{ Yaş Grubu } & \multirow[t]{2}{*}{ Toplam } \\
\hline & & & $60-64$ & $65-69$ & $70-74$ & $75+$ & \\
\hline \multirow{10}{*}{$\begin{array}{l}\text { İnternet sayfasındaki } \\
\text { metinleri okumakta } \\
\text { zorlanıyorum }\end{array}$} & \multirow{2}{*}{$\begin{array}{l}\text { Kesinlikle } \\
\text { Katılmıyorum }\end{array}$} & Sayı & 6 & 5 & 1 & 2 & 14 \\
\hline & & $\%$ & 42.9 & 35.7 & 7.1 & 14.3 & 12.9 \\
\hline & \multirow[t]{2}{*}{ Katılmıyorum } & Sayı & 7 & 5 & 2 & 1 & 15 \\
\hline & & $\%$ & 46.7 & 33.3 & 13.3 & 6.7 & 13.8 \\
\hline & \multirow[t]{2}{*}{ Kararsızım } & Sayı & 3 & 4 & 1 & 0 & 8 \\
\hline & & $\%$ & 37.5 & 50.0 & 12.5 & 0.0 & 7.4 \\
\hline & \multirow[t]{2}{*}{ Katılıyorum } & Sayı & 19 & 13 & 9 & 3 & 44 \\
\hline & & $\%$ & 43.2 & 29.5 & 20.5 & 6.8 & 40.7 \\
\hline & \multirow{2}{*}{$\begin{array}{l}\text { Kesinlikle } \\
\text { Katılıyorum }\end{array}$} & Sayı & 7 & 6 & 7 & 7 & 27 \\
\hline & & $\%$ & 25.9 & 22.2 & 25.9 & 25.9 & 25.0 \\
\hline \multirow{2}{*}{\multicolumn{2}{|c|}{ Toplam }} & Sayı & 42 & 33 & 20 & 13 & 108 \\
\hline & & $\%$ & 38.9 & 30.6 & 18.5 & 12.0 & 100.0 \\
\hline \multirow{10}{*}{$\begin{array}{l}\text { İnternet sayfasındaki } \\
\text { çok fazla renk kulla- } \\
\text { nımımı zorlaştırıyor. }\end{array}$} & \multirow{2}{*}{$\begin{array}{l}\text { Kesinlikle } \\
\text { Katılmıyorum }\end{array}$} & Sayı & 0 & 1 & 0 & 0 & 1 \\
\hline & & $\%$ & 0.0 & 3.0 & 0.0 & 0.0 & 0.9 \\
\hline & \multirow[t]{2}{*}{ Katılmıyorum } & Sayı & 10 & 4 & 3 & 0 & 17 \\
\hline & & $\%$ & 23.8 & 12.1 & 15.0 & 0.0 & 15.7 \\
\hline & \multirow[t]{2}{*}{ Kararsızım } & Sayı & 6 & 7 & 1 & 5 & 19 \\
\hline & & $\%$ & 14.3 & 21.2 & 5.0 & 38.5 & 17.6 \\
\hline & \multirow[t]{2}{*}{ Katılıyorum } & Sayı & 17 & 13 & 8 & 4 & 42 \\
\hline & & $\%$ & 40.5 & 39.4 & 40.0 & 30.8 & 38.9 \\
\hline & \multirow{2}{*}{$\begin{array}{l}\text { Kesinlikle } \\
\text { Katılıyorum }\end{array}$} & Sayı & 9 & 8 & 8 & 4 & 29 \\
\hline & & $\%$ & 21.4 & 24.2 & 40.0 & 30.8 & 26.9 \\
\hline \multirow{2}{*}{\multicolumn{2}{|c|}{ Toplam }} & Sayı & 42 & 33 & 20 & 13 & 108 \\
\hline & & $\%$ & 38.9 & 30.6 & 18.5 & 12.0 & 100.0 \\
\hline \multirow{10}{*}{$\begin{array}{l}\text { İnternet sayfasındaki } \\
\text { metin karakterlerinin } \\
\text { küçük olduğunu dü- } \\
\text { şünüyorum }\end{array}$} & \multirow{2}{*}{$\begin{array}{l}\text { Kesinlikle } \\
\text { Katılmıyorum }\end{array}$} & Sayı & 3 & 5 & 0 & 2 & 10 \\
\hline & & $\%$ & 30.0 & 50.0 & 0.0 & 20.0 & 9.2 \\
\hline & \multirow[t]{2}{*}{ Katılmıyorum } & Sayı & 8 & 2 & 2 & 1 & 13 \\
\hline & & $\%$ & 61.5 & 15.4 & 15.4 & 7.7 & 12.0 \\
\hline & \multirow[t]{2}{*}{ Kararsızım } & Sayı & 7 & 5 & 2 & 2 & 16 \\
\hline & & $\%$ & 43.8 & 31.3 & 12.5 & 12.5 & 14.8 \\
\hline & \multirow[t]{2}{*}{ Katılıyorum } & Sayı & 14 & 11 & 8 & 4 & 37 \\
\hline & & $\%$ & 37.8 & 29.7 & 21.6 & 10.8 & 34.2 \\
\hline & \multirow{2}{*}{$\begin{array}{l}\text { Kesinlikle } \\
\text { Katılıyorum }\end{array}$} & Sayı & 10 & 10 & 8 & 4 & 32 \\
\hline & & $\%$ & 31.3 & 31.3 & 25.0 & 12.5 & 29.6 \\
\hline \multirow{2}{*}{\multicolumn{2}{|c|}{ Toplam }} & & 42 & 33 & 20 & 13 & 108 \\
\hline & & & 38.9 & 30.6 & 18.5 & 12.0 & 100.0 \\
\hline
\end{tabular}

\section{Tartışma ve Sonuç}

Bu sonuçlara göre internet kullanan yaşlıların internete ilişkin "beklentiler", "kullanım", "güvenlik" ve "ergonomi" alt boyutlarında ortalama puanları yüksektir. Benzer şekilde yaş ilerledikçe internet kullanımına yönelik beklenti ve algılarda olumsuzluk artmaktadır. Yaş ilerledikçe metin karakterleri küçük, web sayfaları karmaşık, açılır menüler ve ikonlar karmaşık olarak algılanmaktadır.

Cinsiyet ve evdeki yaşama şekli web sayfaları kullanımına yönelik tutumlar üzerinde etkili değildir. Yaş ilerledikçe internet sayfaları kullanımına yönelik olumsuz tutumlar artmaktadır. Öğrenim düzeyi yükseldikçe güvenlik endişeleri azalmakta, ergonomik yaklaşımlar olumlu yönde değişmektedir.

Ankete katılanların tamamı en az lise mezunudur. \% 9.3'ü ev hanımı, \% 80.7'si bir meslek grubu içinde yer almıştır. Meslek grupları içinde yer alanların, çalışma yaşamları içinde bilgi teknolojileri ile tanışıklığı daha fazladır. Bu nedenle internet kullanımı daha fazladır.

Teknoloji yalnızca üretimde ve günlük faaliyetlerin sürdürülmesinde değil, aynı zamanda yaşlanma ile ilişkili fiziksel ve coğrafi engellerin bir- 
çoğunun ortadan kaldırılmasında ve sosyal ilişkilerin korunmasında yașlı bireyi güçlendirici bir faktör olarak kabul edilmelidir. Özellikle yaşlı bireylerin internet ağı kullanımının arttırılması gerekmektedir. İnternet web sayfalarının güvenliğinin arttırılarak, web sayfası kullanımının e- ticaret vb. boyutta yaşlı bireyler tarafından kullanılabilirliğinin sağlanması gerekmektedir. Teknolojinin birçok olumlu yönü bulunmasına karşın, yaşlılar için olumsuz yönleri de olabileceği kabul edilmelidir. Özellikle, yaşlıları dikkate almayan, uygun beceri veya önlemlerin sağlanamadığı durumlarda, daha fazla hizmet sanal dünyaya yönlendikçe sayısal uçurum ve teknoloji kullanımı ile ilgili kaygı artacaktır. Ayrıca, sayısal uçurumun artması, yaşlıların toplumsal izolasyonunu artırma ve temel hizmetlere erişimi azaltma gibi olumsuz sonuçlara da götürebilir. Sonuç olarak, Bilgi teknolojileri yaşlı bireyin internet ağı kullanımını sağlayacak; web sayfası güvenliğini, web sayfası tasarımını, web sayfalarından beklentilerini ve web sayfaları kullanımı sırasında karşılaşabilecek güçlükleri ortadan kaldırmaya yönelik yaklaşımları yaşama geçirmelidir.

\section{Teşekkür}

Bu çalışma Pamukkale Üniversitesi Bilimsel Araştırma Projeleri Koordinasyon Birimi tarafindan 2018-KKP111 no'lu proje kapsamında desteklenmiştir.

\section{Çıkar Çatışması}

Yazarlar tarafından herhangi bir çıkar çatışması beyan edilmemiştir.

\section{Kaynaklar}

Arning, K. ve Ziefle, M. (2009). Different Perspectives on Technology Acceptance: The Role of Technology Type and Age. In A. Holzinger \& K. Miesenberger (Eds.), USAB 2009, LNCS 5889, (pp. 20-41), SpringerVerlag Berlin Heidelberg.

Charness, N. (2008). Technology as Multiplier Effect for an Aging Work Force. In K.W. Schaie \& R. Abeles (Eds.), Social Structures and Aging Individuals: Continuing Challenges (pp. 167192). New York: Springer.

Charness, N. ve Boot, W.R. (2009). Aging and Information Technology use: Potential and Barriers. Current Directions in Psychological Science, 18(5), 253-258.

Enwald, H., Kangas, M., Keranen, N., Korpelaine, R., Huvila, I. ve Jamsa, T. (2016). Opinions and use of Mobile Information Technology Among Older People in Northern Finland-Preliminary Results of a Population Based Study. ASIST, 14-18.

Festervand, T.A., Meinert, D.B. ve Vitell, S.J. (2011). Older Adult' Attitudes Toward and Adoption of Personal Computer-Based Lifestyle Assistance. Journal of Applied Business Research, 10(2), 13-22.

González, A., Ramírez, M.P. ve Viadel, V. (2015). ICT Learning by Older Adults and Their Attitudes Toward Computer use. Current Gerontology and Geriatrics Research, 1-7.

Hill, R., Betts, L.R. ve Gardner, S.E. (2015). Older Adults' Experiences and Perceptions of Digital Technology: (Dis)empowerment, Wellbeing, and Inclusion. Computers in Human Behavior, 48(C), 415-423.

Kalınkara, V., Başıbüyük, G.Ö. ve Ay, F. (2016). Yașllların Geronteknolojik Ürünleri Kabule Yönelik Tutumları. Yaşlı Sorunları Araştırma Dergisi, 9(2), 1-19.

Kalınkara, V., Tezel, H.E ve Zorlu, T. (2016). Gero(n)teknoloji: Yaşlı ve Teknoloji. İçinde V. Kalınkara (Ed.), Yaşlılı: Disiplinler Arası Yaklaşım, Sorunlar, Cözümler-2. Ankara: Nobel Akademik Yayıncılık.

Mervyn, K. ve Allen, D.K. (2012). Sociospatial Context and Information Behavior: Social Exclusion and the Influence of Mobile Information Technology. Journal of Association for Information Science and Technology, 63(6), 1125-1141.

Rogers, W.A., Stronge, A.J. ve Fisk, A.D. (2005). Technology and Aging. Reviews of Human Factors and Ergonomics, 1(1), 130-171.

Rosen, L.D., Whaling, K., Carrier, L.M., Heever, N.A. ve Rokkum, J. (2013). The Media and Technology Usage and Attitudes Scale: An Empirical Investigation. Comput Human Behav. 29(6), 2501-2511.

Zhou, X. ve Shen, W. (2016). Research on Interactive Device Ergonomics Designed for Elderly Users in the Human-Computer Interaction. International Journal of Smart Home, 10(2), 49-62. 